\title{
Variations in the chemical composition of the solution extracted from a Latosol under fertigation with vinasse ${ }^{1}$
}

\author{
Variação na composição química da solução extraída de um Latossolo fertirrigado \\ com vinhaça
}

\author{
João Paulo Francisco ${ }^{2 *}$, Marcos Vinícius Folegatti², Leonardo Batista Duarte Silva ${ }^{3}$, Jonathas Batista Gonçalves \\ Silva $^{4}$ and Adriano Valentim Diotto 5
}

\begin{abstract}
The aim of this work was to evaluate the change in electrical conductivity and $\mathrm{pH}$ of a soil solution and its composition, with regard to the levels of nitrate and potassium, in a Latosol cultivated with pineapple and subjected to applications of different levels of vinasse. The experiment was conducted in a greenhouse at the Department of Biosystems Engineering of ESALQ/USP. The treatments comprised the application of five levels of vinasse: T1 - $0 \mathrm{~m}^{3} \mathrm{ha}^{-1}, \mathrm{~T} 2-231 \mathrm{~m}^{3} \mathrm{ha}^{-1}$, T3 - $347 \mathrm{~m}^{3} \mathrm{ha}^{-1}$, T4 - $462 \mathrm{~m}^{3} \mathrm{ha}^{-1}$, and T5 $-578 \mathrm{~m}^{3} \mathrm{ha}^{-1}$. Application was every 20 days, using a localised irrigation system with emitters having a nominal flow rate of $4 \mathrm{~L} \mathrm{~h}^{-1}$ and spaced $0.40 \mathrm{~m}$ apart. The applied doses of vinasse were calculated by following the recommendations of CETESB standard P4.231, so that treatment T4 would supply the demand of the pineapple plant for potassium. The solution was collected by means of porous capsule extractors at 30,120 and 210 days from the start of vinasse application. It was found that increases in the volume of the applied levels resulted in greater values for the electrical conductivity of the soil (ECs) and in the concentration of potassium $(\mathrm{K})$ and nitrate $\left(\mathrm{NO}^{3}\right)$, with higher values being obtained in the $0.20 \mathrm{~m}$ layer. The results demonstrated that $\mathrm{pH}$ decreased with increases in the vinasse being applied.
\end{abstract}

Key words: Effluent. Reuse of water. Leaching.

RESUMO - Objetivou-se avaliar a variação na condutividade elétrica e pH da solução do solo e sua composição no que se refere aos teores de nitrato e potássio em um Latossolo sob cultivo da cultura do abacaxi e submetido a aplicações de diferentes níveis de vinhaça. O experimento foi conduzido em casa de vegetação no Departamento de Engenharia de Biossistemas da ESALQ/USP. Os tratamentos foram compostos pela aplicação de cinco níveis de vinhaça, a saber: T1 - $0 \mathrm{~m}^{3} \mathrm{ha}^{-1}$; T2 - $231 \mathrm{~m}^{3} \mathrm{ha}^{-1}$; T3 - $347 \mathrm{~m}^{3} \mathrm{ha}^{-1}$; T4 - $462 \mathrm{~m}^{3} \mathrm{ha}^{-1}$; T5 - $578 \mathrm{~m}^{3} \mathrm{ha}^{-1}$. As aplicações ocorreram em intervalos de 20 dias utilizando-se um sistema de irrigação localizada com gotejadores de vazão nominal de $4 \mathrm{~L} \mathrm{~h}^{-1}$ espaçados em 0,40 m. As doses de vinhaça aplicadas foram calculadas, seguindo recomendações da norma CETESB P4.231, de modo que o tratamento T4 suprisse a demanda por potássio do abacaxizeiro. A coleta da solução foi realizada por meio de extratores de cápsulas porosas após 30; 120 e 210 dias do início da aplicação da vinhaça e verificou-se que o aumento dos volumes de níveis aplicados resultou em maiores valores de Condutividade elétrica do solo (CEs) e concentrações de potássio $(\mathrm{K})$ e nitrato $\left(\mathrm{NO}^{3-}\right)$, com maiores valores obtidos na camada de $0,20 \mathrm{~m}$. Os resultados revelaram que o pH diminuiu à medida em que se aumentavam os volumes de vinhaça aplicados.

Palavras-chave: Efluentes. Reuso de água. Lixiviação.

\footnotetext{
DOI: $10.5935 / 1806-6690.20160027$

*Autor para correspondência

'Recebido para publicação em 09/06/2014; aprovado em 28/11/2015

Parte da Dissertação do primeiro autor ESALQ/USP, trabalho financiado pela FAPESP

${ }^{2}$ Programa de Pós-Graduação Engenharia de Sistemas Agrícolas, Departamento de Engenharia de Biossistemas/ESALQ/USP, Avenida Pádua Dias, 11

Piracicaba-SP, Brasil, 13.418-900, jpbausen@usp.br, mvfolega@usp.br

${ }^{3}$ Departamento de Engenharia/UFRRJ, Seropédica-RJ, Brasil, monitoreambiental@gmail.com

${ }^{4}$ Departamento de Engenharia Sanitária e Ambiental/UFJF, Juiz de Fora-MG, Brasil, jonathasbsilva@gmail.com

${ }^{5}$ University of Nebraska - Lincoln, Lincoln, USA, avdiotto@gmail.com
} 


\section{INTRODUCTION}

Fertigation with vinasse is fairly widespread in sugarcane-producing regions, with results to chemical changes in the soil considered as acceptable (VIANA, 2006). However, if carried out indiscriminately, the high concentration of nutrients present in the vinasse may result in increased leaching and/or salinity of the soil, which can be defined as the concentration of salts dissolved in the soil solution. An increase in salt concentrations can result in less crop development, since plants will spend more energy absorbing water due to the reduction in osmotic potential of the soil water, impairing their metabolic processes (LEONE et al., 2007).

Fertigation with vinassse results in an increase in organic matter, $\mathrm{pH}$, and the levels of exchangeable calcium $(\mathrm{Ca})$, magnesium $(\mathrm{Mg})$ and potassium $(\mathrm{K})$. When correctly applied, around $150 \mathrm{~m}^{3}$ vinasse ha-1 is equivalent to fertilising with $61 \mathrm{~kg}$ nitrogen ha-1, $343 \mathrm{~kg} \mathrm{~K} \mathrm{ha}^{-1}$ and $108 \mathrm{~kg} \mathrm{Ca} \mathrm{ha}^{-1}$ (VIANA, 2006).

Study of the soil solution is important as it is related to the fact that plants absorb free nutrients from the solution, and that it can provide good indicators of soil fertility. However, some parameters, such as the hydrogen-ion potential $(\mathrm{pH})$, are important so that plants absorb without difficulty the nutrients present in the soil solution, since this is an indicator of the chemical condition of the soil with the ability to interfere in the provision of various elements which are essential to plant growth, facilitating or not their absorption (BRADY, 1989).

The ions that make up the soil solution can be adsorbed onto clay particles and organic matter, absorbed by plants or leached down to deeper layers (NOVAIS et al., 2007). According to Neves, Ernani and Simonete (2009), the leaching of ions varies with such physical properties of the soil as texture, structure, profile depth and porosity. The mobility of an ion in the profile depends on its physical and chemical properties and the inherent properties of the colloidal fraction of the soil (RIVERA et al., 2008).

With potassium, an element which is generally present in high concentrations in vinasse, mobility depends on the amounts of available element in the soil. According to Rosolem et al. (2010), the conversion of exchangeable potassium to non-exchangeable potassium can be quick, intensifying the losses due to leaching, as a result of processes to balance these ions in the soil. Sharma and Sharma (2013) found that sandy soils are more prone to potassium leaching, increasing the risk of the possible contamination of groundwater.

For nitrogen, the more this element is added to the soil, the greater will be the levels of nitrate found. As nitrate ions are not adsorbed onto the components of soil fractions, they move easily; nitrate leaching is therefore a physical phenomenon, a result of the low energy involved in its adsorption onto soil particles, and also of its high solubility in water (JADOSKI et al., 2010).

For an effective evaluation of the ions present in the soil solution, constant determinations are necessary that allow the dynamics of these ions to be visualised. One of the methods used for monitoring fluctuations in the concentration of ions in the soil solution is to use porous capsule extractors, as noted by Eloi, Duarte and Soares (2007).

Given the composition of vinasse, and with the focus on electrical conductivity and the concentrations of sodium, potassium and nitrate, if by increasing the vinasse levels applied to a Red-Yellow Latosol cultivated with pineapple there is an increase of ions present in the soil solution, then by monitoring the soil solution throughout the crop, the values of potassium, sodium, nitrate and electrical conductivity will increase with increases in the levels of vinasse.

The aim of this work therefore, was to evaluate changes in electrical conductivity, $\mathrm{pH}$ and levels of nitrate and potassium in the solution of a Latosol cultivated with pineapple and subjected to applications of different levels of vinasse.

\section{MATERIAL AND METHODS}

The experiment was carried out at the Department of Biosystems Engineering of the Luiz de Queiroz College of Agriculture (ESALQ/USP), in the town of Piracicaba, in the State of São Paulo, Brazil. The experiment was conducted in a greenhouse using trenches $3.20 \mathrm{~m}$ long by $0.80 \mathrm{~m}$ wide and $0.50 \mathrm{~m}$ deep. The soil used to fill the trenches corresponds to a profile classified as a RedYellow Latosol (EMBRAPA, 2013), obtained at a depth of $0.30 \mathrm{~m}$ of the arable layer from the ESALQ campus. The chemical and physical characterisation of the soil used in the study can be found in Table 1 .

The experimental area consisted of 20 plots. One experimental unit was represented by a trench lined with sheets of waterproof plastic to prevent movement of the solution between plots and avoid interference between treatments. The experimental units were filled with soil in such a way as to ensure the physical characteristics were homogeneous, such as shape, spatial disposition and a similar volume of soil per unit.

The experiment was set up in a completely randomised design with five treatments and four 
replications, giving a total of 20 experimental units. The treatments comprised the application of five levels of vinasse, namely: T1 - $0 \mathrm{~m}^{3} \mathrm{ha}^{-1}$; $\mathrm{T} 2-231 \mathrm{~m}^{3} \mathrm{ha}^{-1}$; T3 - 347 $\mathrm{m}^{3}$ ha $^{-1}$; $\mathrm{T} 4-462 \mathrm{~m}^{3}$ ha $^{-1}$; T5 - $578 \mathrm{~m}^{3} \mathrm{ha}^{-1}$. Applications took place every 20 days, using a localised irrigation system and emitters with a nominal flow rate of $4 \mathrm{~L} \mathrm{~h}^{-1}$, spaced $0.40 \mathrm{~m}$ apart. The applied volumes of vinasse were calculated following the recommendations of CETESB standard P4.231 (2006), so that treatment T4 would supply the demand of the pineapple for potassium from the vinasse, the remainder receiving doses corresponding to $0 \%(\mathrm{~T} 1), 50 \%(\mathrm{~T} 2), 75 \%(\mathrm{~T} 3), 100 \%(\mathrm{~T} 4)$ and $125 \%$ (T5) of the demand of the crop. The difference between the needs of the plants and the amount of potassium from the vinasse was supplied by mineral fertiliser, using potassium chloride as the source. The pineapple crop was spaced $0.90 \times 0.40 \times 0.40 \mathrm{~m}$ apart, totalling 16 plants for each experimental unit. It is worth noting that fertilisation of the crop was carried out as per agronomic recommendation (RAIJ et al., 1996), so that the only source of variation in the experimental area were the volumes of vinasse applied with each treatment. Table 2 shows the characteristics of the vinasse used in the experiment. It should be noted that the values correspond to the average for the volumes collected and applied during the experiment.

Samples of soil solution were collected at 30 , 120 and 210 days after starting the treatments with the application of vinasse (DAST). Collection was made with solution extractors fitted with porous capsules, at depths of 0.20 and $0.40 \mathrm{~m}$ and a distance of $0.15 \mathrm{~m}$ from the plant and emitters. The vacuum for removal of the samples was applied with a manual vacuum pump, which gave a vacuum intensity of $60 \mathrm{kPa}$. The vacuum was applied 2 hours after completion of the vinasse application, with collection of the solution being made 24 hours after application of the vacuum. The samples of solution were then placed in sealed airtight containers and taken to the Laboratory for Soils and Water Quality at the Department of Biosystems Engineering of ESALQ/USP, where the electrical conductivity (ECs), $\mathrm{pH}$ and concentrations of nitrate $\left(\mathrm{NO}_{3}{ }^{-}\right)$and potassium $\left(\mathrm{K}^{+}\right)$were determined. The ECs and $\mathrm{pH}$ were measured using a computerised conductivity meter and benchtop potentiometer respectively, both with automatic temperature compensation. The $\mathrm{NO}^{3-}$ was determined by spectrophotometry; $\mathrm{K}^{+}$was determined by flame photometry.

Initially, the experimental data were submitted to the Shapiro-Wilk test $(\mathrm{P}>0.01)$ and Levene's test $(\mathrm{P}>0.01)$, to check residual normality and homoscedasticity; analysis of variance was then carried out.

The data were subjected to analysis of variance, with a breakdown of the quantitative effects into orthogonal polynomials according to their significance by

Table 1 - Chemical and physical characterisation of the Red-Yellow Latosol used to fill the trenches

\begin{tabular}{|c|c|c|c|c|c|c|c|c|c|c|c|c|}
\hline \multicolumn{13}{|c|}{ Chemical Characterization } \\
\hline \multirow{3}{*}{ Exchangeable } & $\mathrm{pH}$ & $\mathrm{OM}^{*}$ & $\mathrm{P}$ & $\mathrm{K}$ & $\mathrm{Ca}$ & $\mathrm{Mg}$ & $\mathrm{Al}$ & $\mathrm{H}+\mathrm{Al}$ & SB & CEC & $\mathrm{V}$ & $\mathrm{m}$ \\
\hline & $\left(\mathrm{CaCl}_{2}\right)$ & $\mathrm{g} \mathrm{dm}^{-3}$ & $\mathrm{Mg} \mathrm{dm}^{-3}$ & - & ---- & ----- 1 & $\mathrm{OI}_{\mathrm{c}} \mathrm{C}$ & -3------- & & & \multicolumn{2}{|c|}{----- \% ------ } \\
\hline & 4.8 & 9.0 & 53 & 0.4 & 11 & 7 & 1 & 16 & 18.4 & 34.4 & 53 & 5 \\
\hline \multirow{3}{*}{ Soluble } & $\mathrm{pH}$ & $\mathrm{CE}$ & \multirow[t]{2}{*}{$\mathrm{NO}_{3-}$} & $\mathrm{K}^{+}$ & & $\mathrm{Ca}^{2+}$ & & \multirow{2}{*}{\multicolumn{2}{|c|}{$\mathrm{Mg}^{2+}$}} & \multirow[t]{2}{*}{$\mathrm{SO}_{4}^{2-}$} & & $\mathrm{Na}^{+}$ \\
\hline & (paste) & $\mu \mathrm{S} \mathrm{m} \mathrm{m}^{-1}$ & & & & ----- & & & & & & ------ \\
\hline & 5.87 & 3.4 & 1.48 & \multicolumn{2}{|c|}{0.13} & & & \multicolumn{2}{|c|}{0.48} & \multicolumn{2}{|c|}{0.41} & 0.66 \\
\hline \multicolumn{13}{|c|}{ Physical Characterization } \\
\hline \multicolumn{3}{|c|}{------ Granulometry $(\%)$-------- } & \multicolumn{3}{|c|}{---- Density $\left(\mathrm{g} \mathrm{cm}^{-3}\right)$----- } & \multicolumn{5}{|c|}{ 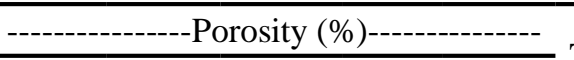 } & \multirow{2}{*}{\multicolumn{2}{|c|}{ Textural Class }} \\
\hline Sand & Silt & Clay & global & \multicolumn{2}{|c|}{ particles } & & & Macro & \multicolumn{2}{|c|}{ Total } & & \\
\hline 73 & 8 & 19 & 1,26 & \multicolumn{2}{|c|}{2,65} & & & 25,48 & \multicolumn{2}{|c|}{52,45} & \multicolumn{2}{|c|}{ Sandy Loam } \\
\hline
\end{tabular}

*OM.-Organic material; S-Sulphur; P-Phosphorus; K-Potassium; Ca-Calcium; Mg-Magnesium; Al-Aluminium; SB-Sum of bases; CEC-Cation exchange capacity; V-Base saturation; $\mathrm{CE}$-Electrical conductivity; $\mathrm{NO}_{3}^{-}$-Nitrate; $\mathrm{K}^{+}$-Potassium; $\mathrm{SO}_{4}^{2-}$-Sulphate; $\mathrm{Na}^{+}-$Sodium

Table 2 - Characterisation of the vinasse used in the treatments

\begin{tabular}{lccccccc}
\hline $\mathrm{COD}\left(\mathrm{mg} \mathrm{L}^{-1}\right)$ & BOD $\left(\mathrm{mg} \mathrm{L}^{-1}\right)$ & $\mathrm{TS}\left(\mathrm{mg} \mathrm{L}^{-1}\right)$ & Conductivity $\left(\mathrm{mS} \mathrm{cm}^{-1}\right)$ & $\mathrm{pH}$ & Nitrate $\left(\mathrm{mg} \mathrm{L}^{-1}\right)$ & Potassium $\left(\mathrm{mg} \mathrm{L}^{-1}\right)$ & Sodium $\left(\mathrm{mg} \mathrm{L}^{-1}\right)$ \\
\hline $36,845.7$ & $6,683.7$ & $33,434.5$ & $7,110.00$ & 4.08 & 124.0 & $3,568.5$ & 49.0 \\
\hline
\end{tabular}

COD-chemical oxygen demand; BOD-Biochemical Oxygen Demand; pH-hydrogen-ion potential 
F-test. The choice of regression model was based on the model with the greatest significant degree by F-test that showed biological behaviour. For analysis of variance and to estimate the parameters of the regression models, the Statistical Analysis System 9.2 software (SAS Institute, 2008) was used.

\section{RESULTS AND DISCUSSION}

The data of the collected variables displayed normal distribution and residual homoscedasticity as per the results of the Shapiro-Wilk test and Levene's test, so data transformation was not necessary.

Table 3 shows a summary of the regression analysis for the electrical conductivity (ECs) of the soil solution at 30, 120 and 210 DAST, at depths of 0.20 and $0.40 \mathrm{~m}$, for the volumes of vinasse applied to the soil. It can be seen that there was a significant quadratic effect $(p<0.01)$ for samples collected at 30 and 120 DAST at depths of 0.20 and $0.40 \mathrm{~m}$. Similarly, a linear significant effect was found $(\mathrm{p}<0.01)$ for the collection carried out at 210 DAST at the two depths being evaluated.

According to Figure 1, it can be seen that the ECs assessed at 30 and 120 DAST followed the quadratic response model for increases in the volume of vinasse applied to the soil. At 210 DAST there was a linear increase in ECs for increases in the volume of vinasse at both depths being evaluated.

According to Neves, Ernani and Simonetti (2009), the addition of each kilogram of potassium to a dystrophic Red Latosol results in an increase of 0.025 $\mathrm{dS} \mathrm{m} \mathrm{m}^{-1}$ in the ECs, being negatively correlated with the $\mathrm{pH}$ and organic matter content of the soil. Greater values for the ECs at the surface were found by Oliveira et al. (2013) and Porto Filho et al. (2011) and, according to those authors, these results may be associated with increased evapotranspiration of the topsoil combined with the use of fertilisers applied to the surface by means of the irrigation water. The same authors state that when there is no physical obstruction, the salts leach beyond the layers being monitored; however this statement does not fit the present research, because the volume of soil available to the plants was limited by a physical barrier (plastic sheeting), preventing the solution from interactions between the plots and the external soil environment. Working with similar trenches, i.e. with plastic sheeting, Lima (2013) also found an increase in surface EC values in rosebushes under fertigation in the greenhouse.

The potential for salt saturation of sandy soils is low, from that point the salts remain free in the soil solution and the leaching process begins. The high values for electrical conductivity found in this study can be attributed to less salt retention by the RedYellow Latosol, the result of a low interaction between the soil and the applied vinasse, keeping in mind the high permeability and low CEC characteristics of the soil.

In Table 4 are shown the results of the regression analysis for $\mathrm{pH}$ values of the soil solution, noting that there was a quadratic effect $(\mathrm{p}<0.01)$ for all samples taken.

The $\mathrm{pH}$ of the soil solution followed a quadratic response model (Figure 2). It can be seen that there was a decrease in $\mathrm{pH}$ throughout the collection time for those treatments which received applications of vinasse. This result may be associated with the release of $\mathrm{CO}_{2}$ and organic acids during breakdown of the organic matter by microorganisms (NOVAIS et al., 2007).

It can be seen that the quadratic behaviour of the $\mathrm{pH}$ was the same for every analysis, barely changing even with vinasse applied to the soil. However, a decrease in $\mathrm{pH}$ was found across the analyses that were carried out,

Table 3 - Summary of regression analysis for the electrical conductivity of the soil solution (ECs) at 30, 120 and 210 DAST, for level of vinasse applied

\begin{tabular}{lccccccc}
\hline & & \multicolumn{5}{c}{ F-TEST } \\
\cline { 3 - 7 } Source of Variation & DF & \multicolumn{3}{c}{ ECs $(0.20 \mathrm{~m})$} & \multicolumn{3}{c}{ ECs $(0.40 \mathrm{~m})$} \\
\cline { 2 - 7 } & & 30 DAST & 120 DAST & 210 DAST & 30 DAST & 120 DAST & 210 DAST \\
\hline Linear & 1 & $63.76^{* *}$ & $114.16^{* *}$ & $59.41^{* *}$ & $135.58^{* *}$ & $54.57^{* *}$ & $22.90^{* *}$ \\
Quadratic & 1 & $11.20^{* *}$ & $60.01^{* *}$ & $2.94^{\text {ns }}$ & $37.35^{* *}$ & $13.29^{* *}$ & $0.03^{\text {ns }}$ \\
Treatment & 4 & $19.64^{* *}$ & $48.63^{* *}$ & $17.30^{* *}$ & $45.80^{* *}$ & $17.01^{* *}$ & $12.84^{* *}$ \\
CV $(\%)$ & - & 7.73 & 8.13 & 15.82 & 8.73 & 9.39 & 23.35 \\
Mean $\left(\mu \mathrm{S} \mathrm{m}^{-1}\right)$ & - & $2,085.20$ & $1,850.17$ & $1,486.50$ & $2,040.83$ & $1,735.03$ & $1,462.37$ \\
\hline
\end{tabular}

${ }_{\text {ns }}$ Not significant at 0.05 by F-test; *, ** Significant at 0.05 and 0.01 by F-test respectively 
Figure 1 - Scatter diagrams and adjustment equations for electrical conductivity of the soil solution at the different times and depths under evaluation, for level of vinasse applied
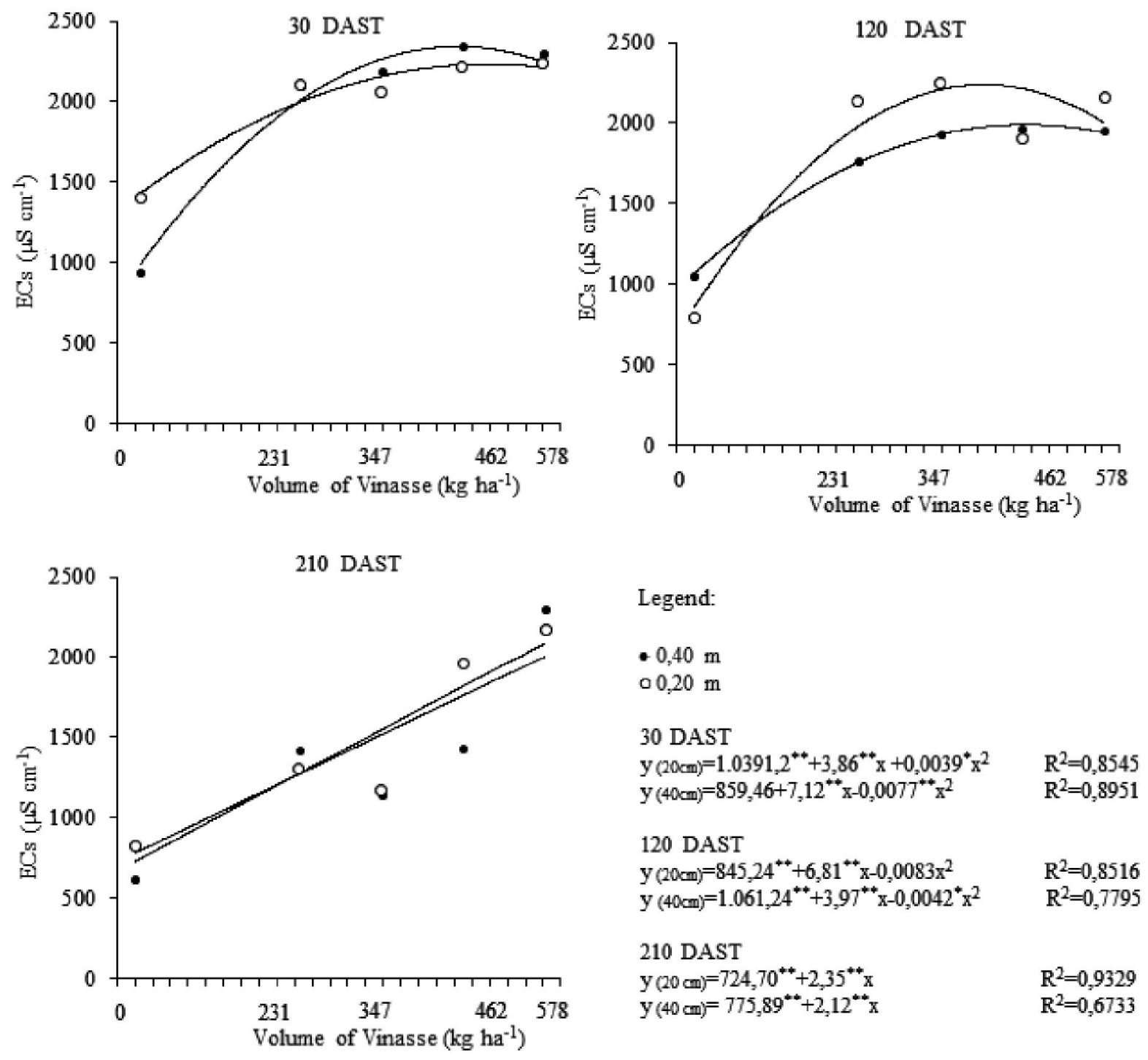

Table 4 - Summary of regression analysis for the pH of the soil solution at 30, 120 and 210 DAST for volume of vinasse applied

\begin{tabular}{lccccccc}
\hline & & \multicolumn{5}{c}{ F-TEST } \\
\cline { 3 - 7 } Source of Variation & DF & \multicolumn{3}{c}{$\mathrm{pH}(0.20 \mathrm{~m})$} & \multicolumn{3}{c}{$\mathrm{pH}(0.40 \mathrm{~m})$} \\
\cline { 3 - 7 } & & 30DAST & $120 \mathrm{DAST}$ & $210 \mathrm{DAST}$ & $30 \mathrm{DAST}$ & $120 \mathrm{DAST}$ & $210 \mathrm{DAST}$ \\
\hline Linear & 1 & $16.24^{* *}$ & $1.64^{\mathrm{ns}}$ & $0.10^{\mathrm{ns}}$ & $10.60^{* *}$ & $0.07^{\mathrm{ns}}$ & $6.29^{*}$ \\
Quadratic & 1 & $16.75^{* *}$ & $185.31^{* *}$ & $117.44^{* *}$ & $28.39^{* *}$ & $112.05^{* *}$ & $32.54^{* *}$ \\
Treatment & 4 & $8.27^{* *}$ & $68.11^{* *}$ & $38.17^{* *}$ & $11.03^{* *}$ & $36.18^{* *}$ & $15.15^{* *}$ \\
CV $(\%)$ & - & 1.36 & 1.62 & 2.65 & 1.46 & 2.48 & 3.98 \\
Mean & - & 6.87 & 5.96 & 5.81 & 7.09 & 5.79 & 5.54 \\
\hline
\end{tabular}

${ }_{\text {ns }}$ Not significant at 0.05 by F-test; *, ** Significant at 0.05 and 0.01 by F-test respectively 
Figure 2 - Scatter diagrams and adjustment equations for $\mathrm{pH}$ of the soil solution at the different times and depths under evaluation, for level of vinasse applied
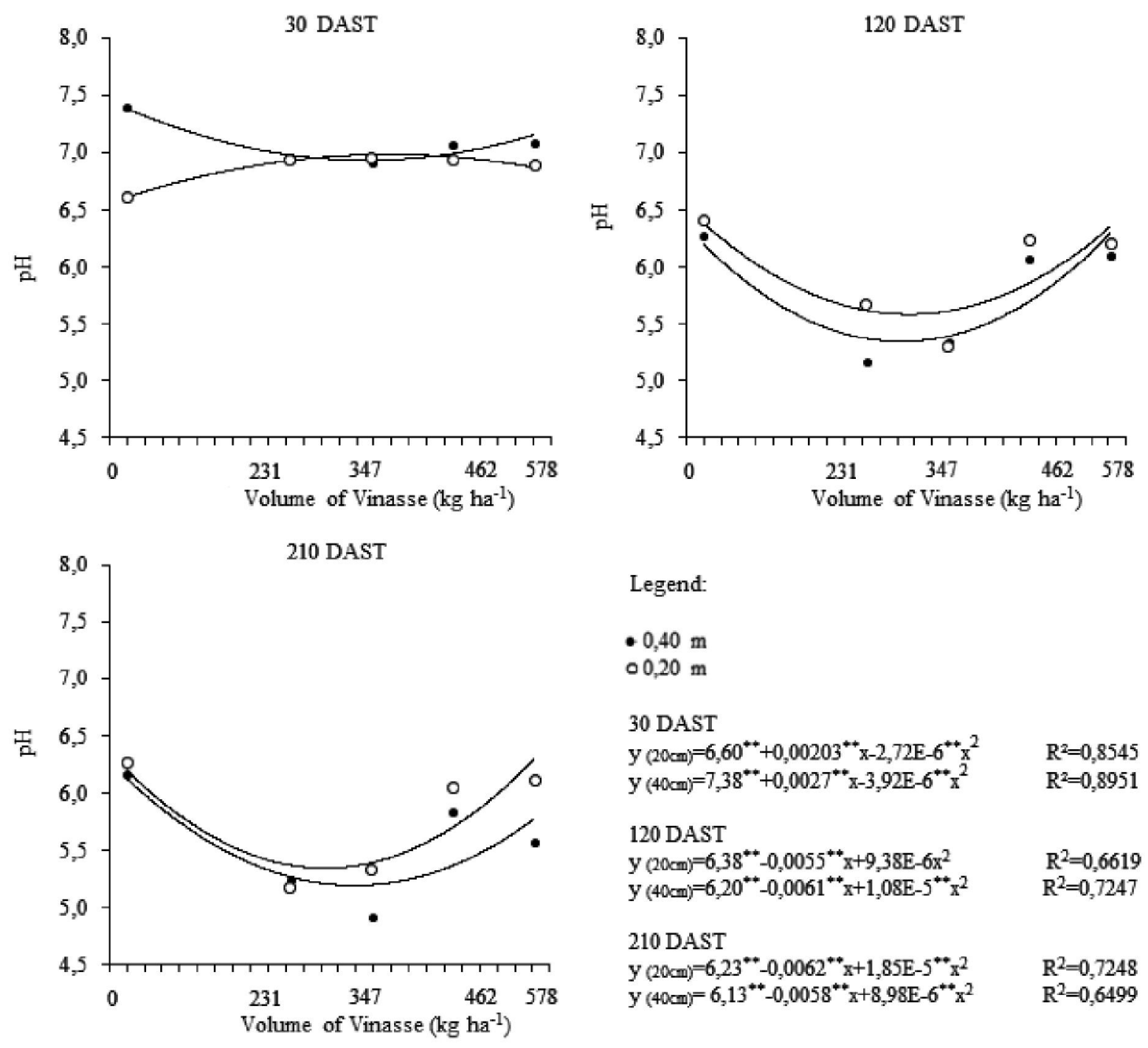

which may be related to the soil having the low buffering capacity characteristic of sandy soils, together with the acid characteristic of the vinasse used in the experiment (Table 2).

Evaluating alterations in the physical and chemical properties of a Latosol, Hati et al. (2007) found no changes in $\mathrm{pH}$ values with successive applications of distillery effluents; the authors attribute this result to the high buffering capacity of the soil where the work was carried out. Rajesh et al. (2009) found an increase in soil pH (7.90 to 8.07) when applying oil-refinery effluent at various time intervals; according to the authors, this result was due to the alkaline characteristics of the effluent and the high concentrations of soluble salts. In evaluating the effect on the soil of applications of wastewater from pig farming,

Cabral et al. (2011) found no significant variation in $\mathrm{pH}$ values at the applied effluent doses; results which were confirmed by Maggi et al. (2013).

It can be seen that here was a significant effect $(\mathrm{p}<0.01)$ for the values of $\mathrm{NO}^{3-}$ present in the soil solution at the different collection times (Table 5).

In Figure 3 can be seen the scatter diagrams and adjustment equations for the times and depth relative to the concentration of $\mathrm{NO}^{3-}$ for the volumes of vinasse applied. Note that at a depth of $0.20 \mathrm{~m}$, the adjustments followed linear models, with an increase in $\mathrm{NO}^{3-}$ concentration as the levels of vinasse increased, whereas the adjustments for the depth of $0.40 \mathrm{~m}$ followed quadratic response models. 
Table 5 - Summary of regression analysis for nitrate values of the soil solution at 30, 120 and 210 DAST for volume of vinasse applied

\begin{tabular}{lccccccc}
\hline & & \multicolumn{5}{c}{ F-TEST } \\
\cline { 3 - 8 } Source of Variation & DF & \multicolumn{3}{c}{$\mathrm{NO}_{3}^{-}(0.20 \mathrm{~m})$} & \multicolumn{3}{c}{$\mathrm{NO}_{3}^{-}(0.40 \mathrm{~m})$} \\
\cline { 3 - 8 } & & 30 DAST & $120 \mathrm{DAST}$ & $210 \mathrm{DAST}$ & $30 \mathrm{DAST}$ & 120 DAST & 210 DAST \\
\hline Linear & 1 & $92.01^{* *}$ & $60.28^{* *}$ & $121.94^{* *}$ & $431.92^{* *}$ & $15.06^{* *}$ & $8.30^{*}$ \\
Quadratic & 1 & $0.05^{\mathrm{ns}}$ & $4.34^{\mathrm{ns}}$ & $4.66^{\mathrm{ns}}$ & $30.37^{* *}$ & $19.67^{* *}$ & $169.73^{* *}$ \\
Treatment & 4 & $26.09^{* *}$ & $30.48^{* *}$ & $35.48^{* *}$ & $122.02^{* *}$ & $10.08^{* *}$ & $65.80^{* *}$ \\
CV $(\%)$ & - & 11.05 & 14.25 & 14.24 & 5.69 & 14.74 & 13.01 \\
Mean $\left(\mathrm{mg} \mathrm{L}^{-1}\right)$ & - & $1,301.51$ & $1,060.65$ & 867.29 & $1,330.85$ & $1,160.61$ & 931.54 \\
\hline
\end{tabular}

${ }^{\text {ns }}$ Not significant at 0.05 by F-test; *,** Significant at 0.05 and 0.01 by F-test respectively

Figure 3 - Scatter diagrams and adjustment equations for nitrate present in the soil solution at the different times and depths under evaluation, for level of vinasse applied
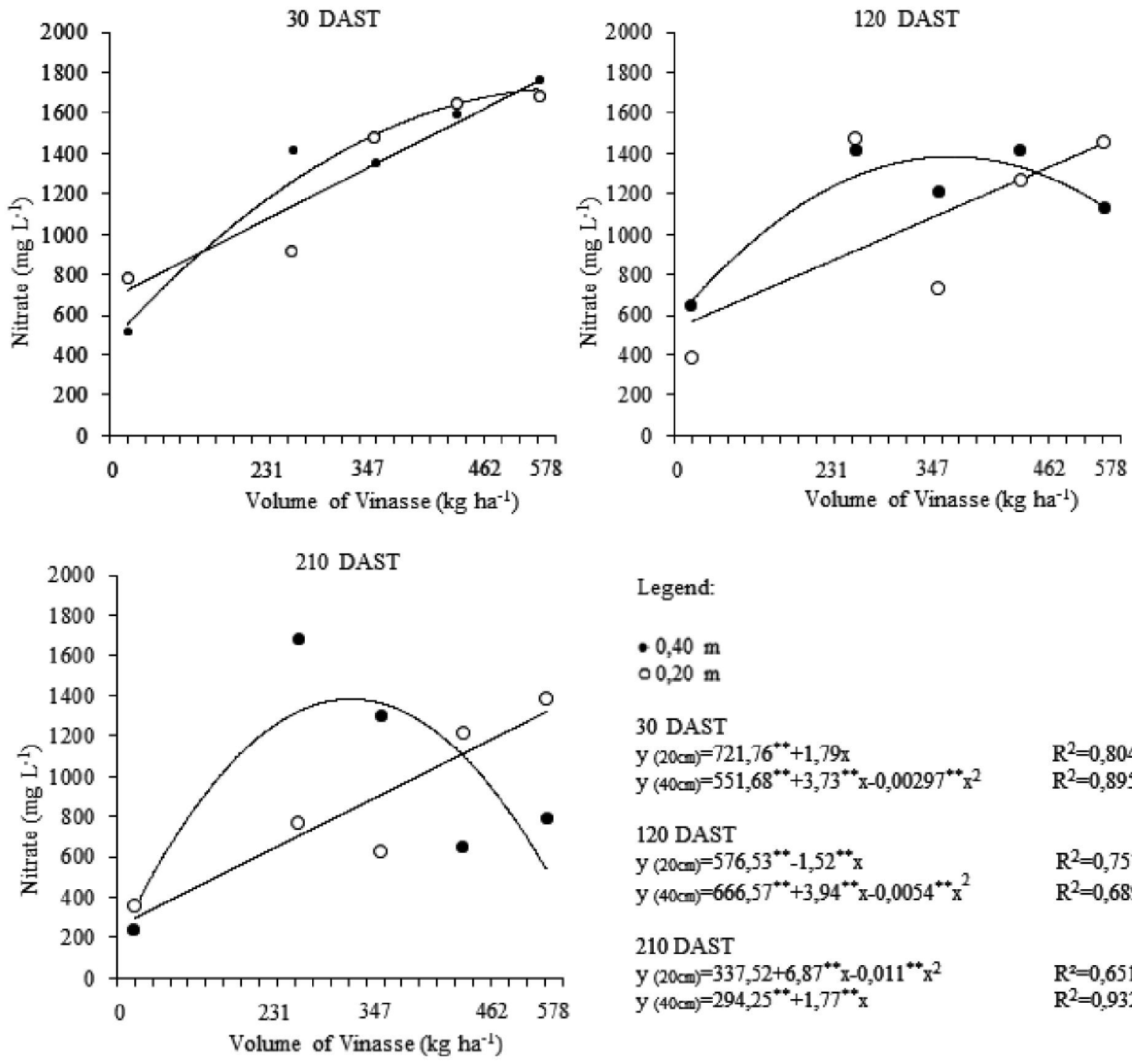

Legend:

- $0,40 \mathrm{~m}$

$0,20 \mathrm{~m}$

30 DAST

$\mathrm{y}(20 \mathrm{~cm})=721,76^{+*}+1,79 \mathrm{x} \quad \mathrm{R}^{2}=0,8047$

$\mathrm{y}(40 \mathrm{~cm})=551,68^{*+}+3,73^{* *} \mathrm{x}-0,00297^{* *} \mathrm{x}^{2} \quad \mathrm{R}^{2}=0,8951$

120 DAST

$y_{(20 \mathrm{~cm})}=576,53^{* *}-1,52^{* *} \mathrm{x} \quad \mathrm{R}^{2}=0,7570$

$y(40 \mathrm{~cm})=666,57^{+*}+3,94^{*+} \mathrm{x}-0,0054^{*+} \mathrm{x}^{2} \quad \mathrm{R}^{2}=0,6899$

210 DAST

$y(20 \mathrm{~cm})=337,52+6,87^{* *} \mathrm{x}-0,011^{* *} \mathrm{x}^{2} \quad \mathrm{R}^{2}=0,6517$

$y(40 \mathrm{~cm})=294,25^{*+}+1,77^{*+} \mathrm{x} \quad \mathrm{R}^{2}=0,9329$ 
It can be seen that the greater the amount of potassium applied through the vinasse, the lower the concentration of nitrate in the $0.40 \mathrm{~m}$ layer when considering evaluations from 120 DAST. According to Venkatesan and Ganapathy (2004), the potassium and nitrogen are synergetic, i.e. the level of nitrogen has an influence on the action of the potassium; the use of nitrogen by the plants in the process of absorption therefore depends on the levels of potassium in the soil. In these treatments, nitrogen absorption was aided by the high doses of potassium supplied to the plants, reducing the presence of $\mathrm{NO}^{3-}$ in the soil solution.

Nitrate levels were higher than those found by Jia et al. (2014), who noted concentrations of $182 \mathrm{mg} \mathrm{L}^{-1}$ in the soil profile with the application of $200 \mathrm{~kg} \mathrm{ha}^{-1}$ and a maximum irrigation level of $525 \mathrm{~mm}$. Perego et al. (2012) found that the addition of $400 \mathrm{~kg} \mathrm{~N} \mathrm{ha}^{-1}$ resulted in nitrate concentrations of up to $110 \mathrm{mg} \mathrm{L}^{-1}$. Studying the leaching process in agricultural areas in France, Jégo, SanchezPerez and Justes (2012) found nitrate leaching of the order of $300 \mathrm{mg} \mathrm{L}^{-1}$. The average potassium application in this study was $115 \mathrm{~kg} \mathrm{ha}^{-1}$, however the low CEC of the soil prevented the adsorption of $\mathrm{NO}^{3-}$, leaving it free in the soil solution. Similar values for concentration were obtained by Lima (2013), who found a nitrate concentration of $1,979.81 \mathrm{mg} \mathrm{L}^{-1}$ at a depth of $0.30 \mathrm{~m}$, using the same soil as in this study.

Tzanakakis et al. (2011) evaluated the soil as a treatment system for agro-industrial effluent, and found that with increases in the volume of the effluents over the time of application, the potential risks of soil and groundwater contamination by nitrates reach dangerous levels. According to the authors, plant species with high rates of nitrogen absorption can reduce these risks, however, additional practices are necessary to control nitrate leaching and the accumulation of this ion in the soil, such as systems for the improvement of pre-application treatments and the dilution of effluents.
In Table 6 is a summary of the regression analysis for potassium concentrations in the soil solution after 30 , 120 and 210 DAST at depths of 0.20 and $0.40 \mathrm{~m}$ for the levels of vinasse applied to the soil. It can be seen that there was a significant effect $(\mathrm{p}<0.01)$ for the levels of $\mathrm{K}$ present in the soil solution at the different collection times.

The only linear significant effect $(\mathrm{p}<0.01)$ was at 30 DAST and a depth of $0.40 \mathrm{~m}$; for the remaining depths and evaluations, a significant quadratic effect ( $\mathrm{p}<0.01)$ was found (Figure 4).

This work found an increase in $\mathrm{K}$ concentrations at the depth of $0.20 \mathrm{~m}$; similarly, Albuquerque et al. (2011) noted that the addition of effluents from the cellulose industry caused an increase in potassium concentrations in the surface layers of a Cambisol. According to the authors, these results were due to the concentration of potassium from the alkaline residue, where the concentration is $1,200 \mathrm{mg} \mathrm{kg}^{-1}$. In relation to the results of this study, the application of levels of vinasse during the DAST is believed to have increased the levels of organic matter in the soil, resulting in an increase in the negative charge of the surface layer, and in the higher values for $\mathrm{K}$ found in this layer.

Comparing the chemical properties of an Argisol that received $150 \mathrm{~m}^{3}$ vinasse $\mathrm{ha}^{-1}$, equivalent to $90 \mathrm{~kg}$ potassium $\mathrm{ha}^{-1}$, with another Argisol to which were applied $90 \mathrm{~kg} \mathrm{~K}_{2} \mathrm{O} \mathrm{ha}^{-1}$, Barros, Viegas and Silva (2010) reported higher concentrations of $\mathrm{K}$ in the surface layer where the vinasse was applied. Gonzalo, Casa Grande and Soares (2005) noted that fertigation with $300 \mathrm{~m}^{3}$ vinasse $\mathrm{ha}^{-1}$ promoted an excess of potassium in the surface layer of the soil, and found that the levels of potassium may be up to eleven times that recommended for $\mathrm{K}_{2} \mathrm{O}$ per hectare for ratoon cane.

Despite $\mathrm{K}$ having a lower leaching potential, it is important to consider the demand of the crop and the cation

Table 6 - Summary of regression analysis for potassium values of the soil solution at 30,120 and 210 DAST, for volume of vinasse applied

\begin{tabular}{|c|c|c|c|c|c|c|c|}
\hline \multirow{3}{*}{ Source of Variation } & \multirow{3}{*}{ DF } & \multicolumn{6}{|c|}{ F-TEST } \\
\hline & & \multicolumn{3}{|c|}{$\mathrm{K}^{+}(0.20 \mathrm{~m})$} & \multicolumn{3}{|c|}{$\mathrm{K}^{+}(0.40 \mathrm{~m})$} \\
\hline & & $30 \mathrm{DAST}$ & 120 DAST & 210 DAST & 30 DAST & 120 DAST & 210 DAST \\
\hline Linear & 1 & $967.07 * *$ & $60.48 * *$ & $53.16 * *$ & $48.59 * *$ & $101.65^{* *}$ & $38.15 * *$ \\
\hline Quadratic & 1 & $145.20 * *$ & $52.34 * *$ & $12.66 * *$ & $2.01^{\mathrm{ns}}$ & $8.76 * *$ & $13.83 * *$ \\
\hline Treatment & 4 & $290.72 * *$ & $32.85 * *$ & $30.82 * *$ & $23.04 * *$ & $29.66 * *$ & $13.52 * *$ \\
\hline $\mathrm{CV}(\%)$ & - & 6.35 & 13.04 & 19.38 & 11.47 & 17.99 & 35.20 \\
\hline Mean $\left(\mathrm{mg} \mathrm{L}^{-1}\right)$ & - & 132.07 & 98.20 & 68.23 & 76.89 & 63.35 & 46.00 \\
\hline
\end{tabular}

${ }^{\text {ns }}$ Not significant at 0.05 by F-test; *,** Significant at 0.05 and 0.01 by F-test respectively 
Figure 4 - Scatter diagrams and adjustment equations for potassium concentrations present in the soil solution at the different times and depths under evaluation, for level of vinasse applied
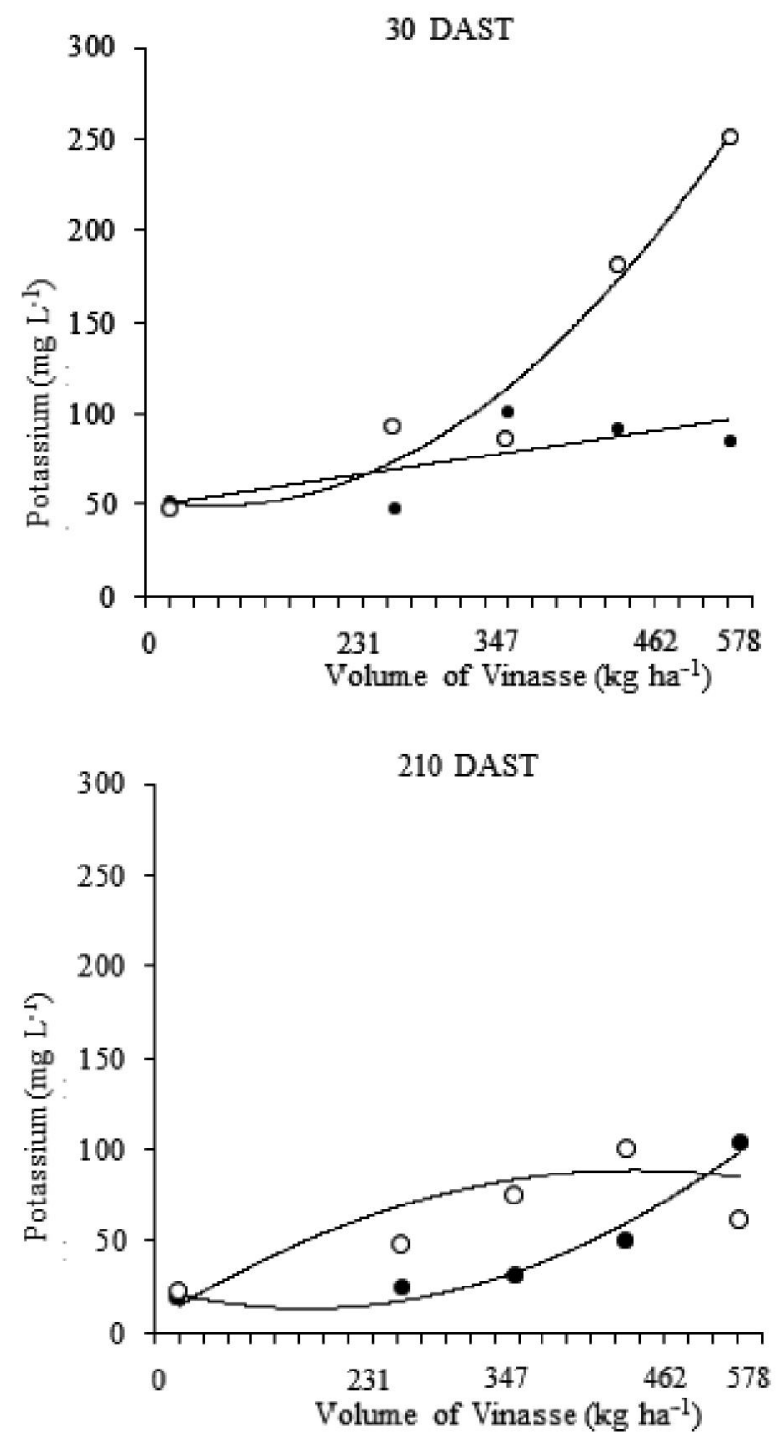

retention capacity of the soil when deciding the rate of vinasse to be applied, in order to minimise the environmental impacts caused by the agricultural use of the residue.

The results of this study are similar to those found by Bebé et al. (2009), who observed a decrease in the levels of potassium with increasing depth. According Novais et al. (2007), potassium concentrations in Brazilian soils are less than $20 \mathrm{mg} \mathrm{L}^{-1}$, even in well-fertilised soils, and because of this the amount of potassium in the solution tends to exhaust itself quickly if not replaced. Based on this observation, the supply of potassium by means of agro-industrial effluents could be an interesting, low-cost alternative for producers, providing that the composition of the effluent, the absorption capacity of the plants and

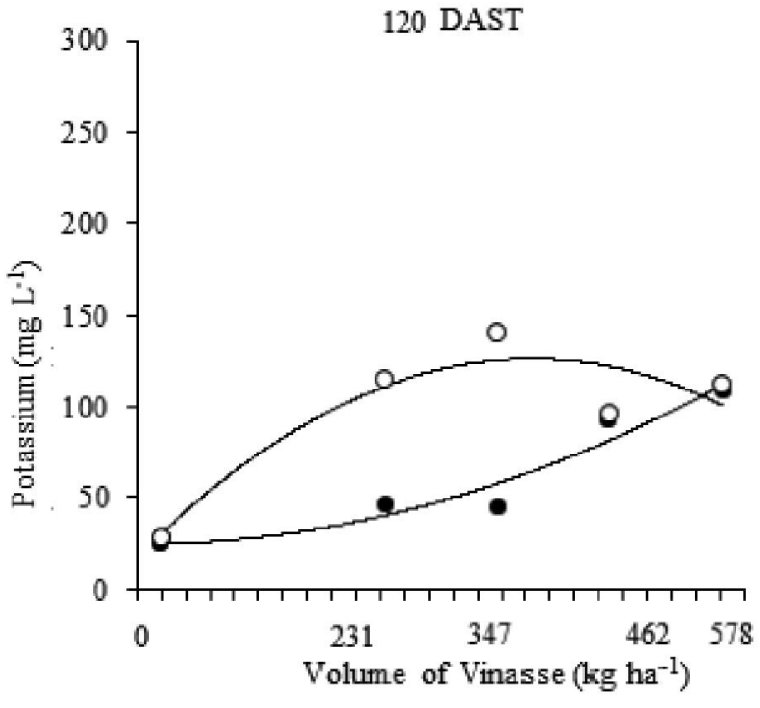

Legend:

- $0,40 \mathrm{~m}$

$0,20 \mathrm{~m}$

30 DAST

$\mathrm{y}_{(20 \mathrm{~cm})}=51,07^{* *}-0,07 \mathrm{x}+7,2 \mathrm{E}-4^{* *} \mathrm{x}^{2} \quad \mathrm{R}^{2}=0,8545$

$\mathrm{y}(40 \mathrm{~cm})=50,87^{++}+0,079^{++} \mathrm{x} \quad \mathrm{R}^{2}=0,8951$

120 DAST

$\mathrm{y}_{(20 \mathrm{~cm})}=30,09^{+*}+0,51^{+*} \mathrm{x}-0,00066^{*+} \mathrm{x}^{2} \quad \mathrm{R}^{2}=0,9329$

$\mathrm{y}(40 \mathrm{~cm})=24,61^{*+}-0,012 \mathrm{x}-2,41 \mathrm{E}-6^{*} \mathrm{x}^{2} \quad \mathrm{R}^{2}=0,8696$

210 DAST

$\mathrm{y}_{(20 \mathrm{~cm})}=14,36^{*}+0,32^{* *} \mathrm{x}-3,36 \mathrm{E}-4^{*} \mathrm{x}^{2} \quad \mathrm{R}^{2}=0,9329$

$\mathrm{y}(40 \mathrm{~cm})=21,03^{*}-0,11 \mathrm{x}+9,29 \mathrm{E}-4^{4+} \mathrm{x}^{2} \quad \mathrm{R}^{2}=0,7427$

the chemical and physical characteristics of the soil, as well as the depth of the water table, are all considered.

It is important to mention that the results of this study were obtained under controlled conditions in a greenhouse, with no interference from rainfall. Contrasting results may therefore be obtained in open areas where, for example, rainfall can affect the dynamics of these elements in the soil.

\section{CONCLUSION}

1. The electrical conductivity of the soil increased and the $\mathrm{pH}$ decreased with increases in the volume of vinasse applied; 
2. Increases in the volume of vinasse applied, resulted in high concentrations of $\mathrm{NO}^{3-}$ in the soil solution, despite the synergism between this nutrient and the $\mathrm{K}$ favouring its absorption;

3. Greater concentrations of $\mathrm{K}$ were found at a depth of $0.20 \mathrm{~m}$.

\section{ACKNOWLEDGEMENT}

This work is part of the lead author's dissertation, under project (2012 04806-7), funded by FAPESP.

\section{REFERENCES}

ALBUQUERQUE, J. A. et al. Aplicação de resíduo alcalino na superfície de Cambissolos. Bragantia, v. 70, n. 4, p. 888-898, 2011.

BARROS, R. P. D.; VIEGAS, P. R. A; SILVA, T. L. Alterações em atributos químicos de solo cultivado com cana-de-açúcar e adição de vinhaça chemical changes in soils cultivated with sugarcane and addition of vinasse. Pesquisa Agropecuária Tropical, v. 40, n. 3, 2010.

BEBÉ, F. V. et al. Avaliação de solos sob diferentes períodos de aplicação com vinhaça. Revista Brasileira de Engenharia Agrícola e Ambiental, v. 13, n. 6, p. 781-787, 2009.

BRADY, N.C. Natureza e propriedades dos solos. Rio de Janeiro: Freitas Bastos, 1989. 878 p.

CABRAL, J. R. et al. Impacto da água residuária de suinocultura no solo e na produção de capim-elefante. Revista Brasileira de Engenharia Agrícola e Ambiental, v. 15, n. 8, p. 823-831, 2011.

COMPANHIA DE TECNOLOGIA DE SANEAMENTO AMBIENTAL. Vinhaça: critérios e procedimentos para aplicação no solo agrícola. P4.231. São Paulo, 2006. 12 p.

ELOI, W. M.; DUARTE, S. N.; SOARES, T. M. Níveis de salinidade e manejo da fertirrigação sobre características do tomateiro cultivado em ambiente protegido. Revista Brasileira de Ciências Agrárias, v. 02, n. 01, p. 83-89, 2007.

EMPRESABRASILEIRADEPESQUISAAGROPECUÁRIA. Sistema brasileiro de classificação de solos. Brasília: Embrapa Produção de Informação, 3ed., Rio de Janeiro: EMBRAPA. 2013. 353 p.

GONZALO, D. D. P.; CASA GRANDE, J. C.; SOARES, M. R. Lixiviação de potássio em solos adubados com vinhaça. In: CONGRESSO BRASILEIRO DE CIÊNCIA DO SOLO, 30., 2005, Recife. Resumos... Recife: SBCS, 2005. 1 CD-ROM. HATI, K. M. et al. Soil properties and crop yields on a vertisol in India with application of distillery effluent. Soil and Tillage Research, v. 92, n. 1/2, p. 60-68, 2007.
JADOSKI, S. O. et al. Características da lixiviação de nitrato em áreas de agricultura intensiva. Revista Brasileira de Tecnologia Aplicada nas Ciências Agrárias, v. 3, n. 1, 2010.

JÉGO, G.; SÁNCHEZ-PÉREZ, J. M.; JUSTES, E. Predicting soil water and mineral nitrogen contents with the STICS model for estimating nitrate leaching under agricultural fields. Agricultural Water Management, v. 107, p. 54-65, May 2012.

JIA, X. et al. Effect of different nitrogen and irrigation treatments on yield and nitrate leaching of summer maize (Zea mays L.) under lysimeter conditions. Agricultural Water Management, v. 137, p. 92-103, 2014.

LEONE, A. P. et al. A field experiment on spectrometry of crop response to soil salinity. Agricultural Water Management, v. 89 , n. $1 / 2$, p. $39-48,2007$.

LIMA, C. J. G. D. S. Manejo da fertirrigação no cultivo de roseiras em ambiente protegido. 2013. 164 f. Tese (Doutorado em Irrigação e Drenagem) - Escola Superior de Agricultura "Luiz de Queiroz", Universidade de São Paulo, Piracicaba, 2013.

MAGGI, C. F. et al. Impacts of the application of swine wastewater in percolate and in soil cultivated with soybean. Engenharia Agrícola, v. 33, n. 2, p. 279-290, 2013.

NEVES, L. S. D.; ERNANI, P. R.; SIMONETE, M. A. Mobilidade de potássio em solos decorrente da adição de doses de cloreto de potássio. Revista Brasileira de Ciência do Solo, v. 33, n. 1, p. 25-32, 2009.

NOVAIS, R. F. et al. Fertilidade do solo. Viçosa, MG: Sociedade Brasileira de Ciência do Solo, 2007. 1017 p.

OLIVEIRA, F. A. et al. Manejos da fertirrigação e doses de N e K no cultivo de pimentão em ambiente protegido. Revista Brasileira de Engenharia Agrícola e Ambiental, v. 17, n. 11, p. 1152-1159, 2013.

PEREGO, A. et al. Nitrate leaching under maize cropping systems in Po Valley (Italy). Agriculture, Ecosystems \& Environment, v. 147, p. 57-65, 2012.

PORTO FILHO, F. Q. et al. Evolução da salinidade e pH de solo sob cultivo de melão irrigado com água salina Evolution of salinity and $\mathrm{pH}$ of soil cultivated with melon irrigated with brackish water. Revista Brasileira de Engenharia Agrícola e Ambiental, v. 15, n. 11, p. 1130, 2011.

RAIJ, B. van. et al. (Ed.). Recomendações de adubação e calagem para o Estado de São Paulo. 2.ed. Campinas: IAC, 1996. p. 8-13. ( Boletim Técnico, 100).

RAJESH, D. Impact assessment of soils treated with refinery effluent. European Journal of Soil Biology, v. 45, n. 5/6, p. 459-465, 2009.

RIVERA, N. C. R. et al. Modelo aplicado à dinâmica da água e do potássio no solo sob irrigação por gotejamento: análise de sensibilidade Model applied to water and potassium 
dynamics under drip irrigation: sensitivity analysis. Engenharia Agrícola, v. 28, n. 3, p. 448, 2008.

ROSOLEM, C. A. et al. Potassium leaching as affected by soil texture and residual fertilization in tropical soils. Communications in soil science and plant analysis, v. 41, n. 16, p. 1934-1943, 2010.

SAS INSTITUTE. SAS user's guide: statistics. Version 9.2. Cary, 2008. 1028 p.

SHARMA, V.; SHARMA, K. N. Influence of accompanying anions on potassium retention and leaching in potato growing alluvial soils. Pedosphere, v. 23, n. 4, p. 464-471, 2013.
TZANAKAKIS, V. A. et al. Effluent application to the land: Changes in soil properties and treatment potential. Ecological Engineering, v. 37, n. 11, p. 1757-1764, 2011.

VENKATESAN, S.; GANAPATHY, M. N. K. Impact of nitrogen and potassium fertilizer application on quality of CTC teas. Food Chemistry, v. 84, n. 3, p. 325-328, 2004.

VIANA, A. B. Tratamento anaeróbio da vinhaça em reator UASB operado em temperatura na faixa termofílica $\left(55^{\circ} \mathrm{C}\right) \mathrm{e}$ submetido ao aumento progressivo de carga orgânica. 2006. 102 f. Dissertação (Mestrado em Hidráulica e Saneamento) Escola de Engenharia de São Carlos, Universidade de São Paulo, São Carlos, 2006. 